\title{
Relative persistence of commonly used forestry herbicides for preventing the establishment of broom (Cytisus scoparius) seedlings in New Zealand plantations
}

Hop Tran ${ }^{1}$, Kerry C Harrington ${ }^{1 *}$, Alastair W Robertson ${ }^{1}$ and Michael S Watt ${ }^{2}$

\begin{abstract}
Background: Many of the herbicides used in site preparation of forests and during initial selective weed management can persist in the soil for several months, killing or stunting seedlings of broom (Cytisus scoparius (L.) Link) as they establish. The objective of this research was to determine the relative persistence and effect over time of the herbicides most widely applied within radiata pine (Pinus radiata D.Don) plantations in New Zealand on broom survival and growth.
\end{abstract}

Methods: Eleven herbicide treatments were applied in early summer to a Tokomaru silt loam soil. Soil samples were collected from each treatment at fortnightly intervals for up to a year. The samples were placed into pots and immediately sown with scarified viable broom seeds in a heated glasshouse. Relative growth and biomass of seedlings were determined as the ratio of growth and survival in each treatment relative to growth and survival in an untreated control. Logistic curves were fitted to recorded values of relative growth and survival over time and the time to reach 50 and $95 \%$ of the vigour of the plants in the untreated control was determined.

Results: The treatments can be approximately ranked in the following order from most to least persistent: triclopyr/ picloram $>$ high rate of clopyralid $>$ high rate of hexazinone $>$ terbuthylazine/hexazinone $>$ low rate of hexazinone $>$ low rate of clopyralid $>$ high rate of terbuthylazine $>$ triclopyr $>$ high rate of metsulfuron-methyl $>$ low rate of terbuthylazine > low rate of metsulfuron-methyl.

Conclusion: As the rate of triclopyr/picloram used in this work is too phytotoxic to be used selectively over newly planted radiata pines, this treatment would only be suitable prior to tree planting so residual activity would control seedlings that develop after scrub clearance. For post-plant weed management operations, results show hexazinone and high rates of clopyralid to be useful for long-term management of broom as both these herbicides have low phytotoxicity to radiata pine. When combined with low rates of triclopyr and picloram, clopyralid could provide an effective treatment that could be used in combination with oversown or naturally occurring grasses to manage broom.

Keywords: Bioassay; Broom; Clopyralid; Herbicide; Hexazinone; Metsulfuron-methyl; Picloram; Residue; Terbuthylazine; Triclopyr

\footnotetext{
* Correspondence: K.Harrington@massey.ac.nz

${ }^{1}$ Institute of Agriculture and Environment, Massey University, Palmerston

North 4442, New Zealand

Full list of author information is available at the end of the article
} 


\section{Background}

During plantation establishment, competition from weeds is often an important constraint for the growth and survival of young trees (White et al. 1990; Balandier et al. 2006; Wagner et al. 2006). Weed species compete and reduce crop tree growth by using water, nutrients and light (Nambiar and Sands 1993; Löf 2000; Wang et al. 2000; Richardson and Whitehead 2002). The main reason for practising weed management during plantation establishment is to improve survival and growth rates of young trees by decreasing competition from weed species (Balneaves 1982; Walstad and Kuch 1987).

Broom (Cytisus scoparius L. (Link)) is a large, deciduous leguminous shrub that can grow rapidly to form dense stands, excluding native plants and altering community structure of prairies, woodlands and young forests (Bossard and Rejmánek 1994; Wearne and Morgan 2004; Caldwell 2006; Prévosto et al. 2006; Wearne and Morgan 2006). Abundant seed production in combination with seed longevity of up to 81 years (Turner, 1933) results in the accumulation of persistent seed under forest stands, making the long-term management of this weed difficult (Oneto et al. 2010).

As broom is fast growing and competes strongly for both water and light, it is one of the most serious competitors of radiata pine (Pinus radiata D.Don) plantations in New Zealand (Richardson and Whitehead 2002). Studies carried out on both moist (Richardson et al. 1996; Richardson et al. 1999) and dry sites (Clinton et al. 1995; Richardson et al. 1997; Richardson and Whitehead 2002; Watt et al., 2003) have shown that broom can have a large negative influence on radiata pine growth during the establishment phase. These effects persist in stands that are slow to close canopy. Understorey broom has been shown to compete strongly with radiata pine for water and retard tree growth at stand ages between 9-12 years (McCracken 1995; Richardson and Whitehead 2002).

Although a number of management measures have been used to reduce competition from broom, few studies report on the efficacy of these methods (Oneto et al. 2010). Manual and mechanical methods, such as cutting or hand pulling, may be effective in controlling broom seedlings and small shrubs but are labour intensive and costly over large areas as repeated actions are required (Hoshovsky 1986; Bossard 1990). Until viable nonchemical methods of management are determined, the routine application of herbicides during the plantation establishment phase (Richardson 1993) will continue to play an important part in successful management of broom.

Chemical weed management is preferred over manual weeding or over-sowing of cover crop species, as herbicides are less expensive to apply and more effective than other methods (Gous 2005). Herbicides with appropriate selective activity suppress competing weeds so that the desired trees can grow more quickly (Gratkowski 1975; Morash and Freedman 1989). Some herbicides, such as glyphosate, kill weeds on application and leave no residue in the soil. Others, called residual herbicides, can continue to be effective for some time after application because they persist in the soil. Some of these residual herbicides, such as clopyralid, are used more for their knockdown effect at application, whereas others, such as terbuthylazine, are used more for their persistence than their knockdown ability. An important determinant of the success of residual herbicides is their persistence in the soil and consequently the post-application duration over which the herbicide will continue to prevent seed germination, seedling emergence and/or development (Ketchum and Rose 2003).

Herbicide persistence is usually compared by estimating a half-life $\left(D T_{50}\right)$, which is the time taken for its activity to be reduced by $50 \%$ through dissipation from the soil (Helling 2005). Half-life can be determined directly by analysing changes in residual herbicide levels in soil samples using chromatographic methods (Roy et al. 1989), or indirectly with bioassays (Sahid and Teoh 1994) which measure the ability of indicator species to successfully grow within treated soil (Günther et al. 1989). Persistence of herbicides within soil varies depending on herbicide chemical structure and mechanism of action, soil properties (soil type and soil organic matter), meteorological factors (temperature and rainfall) and microbial degradation (Helling 2005).

A recent survey of New Zealand plantation owners has shown that the major herbicides used by the forest industry are terbuthylazine, glyphosate, hexazinone, clopyralid, metsulfuron-methyl, triclopyr and picloram (Rolando et al. 2013). Two of these (terbuthylazine and hexazinone) were prohibited temporarily for use in forests certified by the Forest Stewardship Council (FSC). Criteria for prohibition relate to the persistence and/or toxicity of specific herbicides in the environment. It was possible for the owners of certified forests to obtain a derogation from the FSC during this period of prohibition that allowed them to use limited amounts of prohibited herbicides in a controlled way if they supported research into alternative chemical and non-chemical weed management options.

As the prohibition of terbuthylazine and hexazinone was under review by the FSC when this trial was conducted, studying the effectiveness of these herbicides against broom was deemed worthwhile. Hexazinone is known to provide good knockdown and residual management of a range of perennial weeds. This herbicide is typically applied in the spring, rather than in the winter soon after planting, and can continue to inhibit weed development for up to two years when applied at $4.0 \mathrm{~kg}$ ai 
(active ingredient) $\mathrm{ha}^{-1}$ (Cameron and Stokes 1978). In Washington and Oregon (USA), hexazinone applied at $2.2 \mathrm{~kg}$ ai ha ${ }^{-1}$ was found to provide both effective and lasting management of grasses and forbs after preplanting and post-planting applications (Dimock et al. 1983). Research conducted in southern New Mexico with applications of hexazinone at 0.56 and $1.12 \mathrm{~kg}$ ai ha ${ }^{-1}$ showed early season grass and forb control of 65 and 90\%, respectively (Fisher et al. 1986). Although these rates were safe for conifer growth, higher rates $\left(6.0-8.0 \mathrm{~kg}\right.$ ai ha $\left.{ }^{-1}\right)$ were found to increase mortality of loblolly pine (Pinus taeda L.) (Fitzgerald and Fortson 1979). In New Zealand, hexazinone is registered for killing weeds during site preparation and for the release of radiata pine during the postestablishment phase at rates as high as $7.5 \mathrm{~kg}$ ai ha ${ }^{-1}$ though label recommendations state that broom is a less susceptible species and will only be controlled while seedlings are very young even at this high rate (Young 2013).

Hexazinone is degraded by light and microbial activity to various metabolites and is also readily leached in soil (USDA-FS 1984a). The persistence of hexazinone varies with soil type, environmental conditions (Rhodes 1980; Rahman 1981; Harrington et al. 1982; USDA-FS 1984a), and timing of application (Coackley and Moore 1977) with a half-life ranging from 10-180 days (Gaskin and Zabkiewicz 1986; Khan and Liang 1989; Michael and Neary 1993). For example, hexazinone was found to be more persistent under cold and dry conditions than under warm and wet conditions and was more mobile in a sandy loam soil than in a silt loam soil (Rahman 1981). These results are in agreement with other studies in North America (Rhodes 1980; Feng 1987; Roy et al. 1989) and New Zealand (Close et al. 2008; Sarmah et al. 2009). Coackley and Moore (1977) assessed the persistence of hexazinone in various radiata pine plantations under different climatic conditions throughout New Zealand and suggested that the optimum time of application was September (early spring) compared with other times assessed due to less rainfall after this time and thus less loss from leaching.

Terbuthylazine is a residual herbicide used either by itself or in combination with hexazinone, and is absorbed mainly by roots but also through the foliage (Lavy et al. 1989; Gous 2005). Its tolerance by coniferous trees makes it a popular choice in forestry (Lavy et al. 1989) and it is one of the most commonly used herbicides in radiata pine plantations in New Zealand (Wang et al. 2010) for pre- and post-emergent management of annual and perennial grass and broadleaf weeds (James et al. 1998; Gous 2005). The half-life of terbuthylazine in the soil has been reported to vary between 5 and 116 days after treatment (DAT) depending on soil characteristics and temperature (Sahid and Teoh 1994; James et al. 1998; Watt et al. 2010).
Metsulfuron-methyl is not tolerated by radiata pine so this herbicide is only used for site preparation, and trees cannot be planted until 2 months after application to allow for persistence of the herbicide within the soil (Young 2013). It is commonly applied for clearance of woody weeds such as gorse (Ulex europaeus L.) and blackberry (Rubus fruticosus agg.) prior to planting radiata pine either alone or, more commonly, in combination with glyphosate (Gous 2005). Metsulfuron-methyl is considered to have high soil activity and a soil half-life that varies between 5 and 63 days (Ismail and Lee 1995; Günther et al. 1989; Trabue et al. 2006), with the principal modes of degradation being microbial breakdown and chemical hydrolysis (Beyer et al. 1987). Metsulfuronmethyl can have high persistence and mobility depending on the environmental conditions (Sarmah et al. 2000), with a negative relationship between sorption and soil $\mathrm{pH}$ (Walker et al. 1989; Walker and Welch 1989). Rahman et al. (1991)) reported that the persistence of metsulfuronmethyl was shorter in soils with lower $\mathrm{pH}$ (below 5.5) and/or high organic matter (above 10\% organic carbon), and phytotoxic residues differed between time of applications (autumn $>$ spring). James et al. (2004) found that when $0.012 \mathrm{~kg}$ ai ha ${ }^{-1}$ metsulfuron was applied to a silt loam soil, between $75 \%$ and $90 \%$ of the herbicide had degraded 56 DAT, and they reported that similar work at four sites around New Zealand found the persistence ranged from 28 days to more than 63 days.

Triclopyr is used for clearing scrub weeds during site preparation, either by itself or in combination with picloram (Davenhill 1997). When used prior to planting pine seedlings, rates as high as $6.0 \mathrm{~kg}$ ai ha ${ }^{-1}$ are recommended, with lower rates of up to $1.2 \mathrm{~kg}$ ai ha ${ }^{-1}$ when spraying over newly planted (or young) radiata pine seedlings for the selective control of broom (Young 2013). Triclopyr is a phytotoxic pyridine compound that has been developed to control broadleaf weeds and brush (Jotcham et al. 1989). The soil persistence of triclopyr is variable with the half-life ranging from 10 to 100 days (Cox 2000). Triclopyr applied at $2.64 \mathrm{~kg} \mathrm{ai} \mathrm{ha}^{-1}$ was moderately persistent in some Canadian sandy and clay forestry soils with times to $50 \%$ and $90 \%$ disappearance at 14 and 20 DAT, respectively (Stephenson et al. 1990). Residual triclopyr (applied at $3.5 \mathrm{~kg}$ ai $\mathrm{ha}^{-1}$ to control infestations of the exotic vine, kudzu (Pueraria montana (Lour.) Merr.) in loblolly pine plantation establishment sites) was more persistent during a drier period (170 DAT) following spot treatment of regenerating kudzu plants (applied only to the kudzu plants and soil in the immediate vicinity) than during a wet period (29 DAT) (Berisford et al. 2006), probably because this herbicide is degraded quickly through microbial activity which is more likely to occur under warm, moist conditions (USDA-FS 1984b). 
The two pyridine herbicides, clopyralid and picloram, are used within New Zealand radiata pine forests for management of broom and some other weeds such as gorse, woolly nightshade (Solanum mauritianum Scop.), tree lucerne (Chamaecytisus palmensis (Christ) F.A.Bisby\&K.W.Nicholls), wattles (Racosperma spp.) and ragwort (Jacobaea vulgaris Gaertn.). However, picloram is normally used in combination with triclopyr for both site preparation and (at lower rates) for selective management, while clopyralid is used with triclopyr and picloram for selective management of young broom after planting during plantation establishment (Davenhill 1997; Young 2013). Picloram aerially sprayed at $1.1 \mathrm{~kg}$ ai ha ${ }^{-1}$ on gorse can remain active in the soil for up to 450 days (MacDiarmid 1975) but residual triclopyr was not detected at 120 days after the application of $12.0 \mathrm{~kg}$ ai ha ${ }^{-1}$ (MacDiarmid 1977). Clopyralid can remain active for 60420 days depending on the rate applied and environmental conditions (Pik et al. 1977; Bovey and Richardson 1991; Cox 1998).

The persistence of these herbicides, whether used during site preparation or for spraying over newly planted (or young) radiata pine seedlings, may provide management of new broom seedlings in the weeks following their application, and this has been shown by Harrington (2014) for clopyralid and aminopyralid. Published information related to the residual activity of the herbicides discussed is available but often provides broad ranges and usually gives limited indication of how soon after application that broom seedlings will no longer be affected. The objective of this research was to determine the effect over time on broom survival and growth of the herbicides most widely applied within radiata pine plantations in New Zealand.

\section{Methods}

\section{Study site and preparation}

The experiment was conducted at a flat site located at the Moginie Pasture and Crop Research Unit of Massey University, Palmerston North, New Zealand (40 23'S, $175^{\circ} 36^{\prime} \mathrm{E}$ ). The site was previously in pasture grazed by sheep and was cleared on 19 November 2008 (two weeks before the start of the experiment) by spraying with glyphosate (Roundup Transorb, Nufarm Ltd; $2.2 \mathrm{~kg}$ ai ha ${ }^{-1}$ ) to kill all pasture species present. Thirty-six plots of 1 $\mathrm{m}^{2}(1 \times 1 \mathrm{~m})$ were then pegged out with $1 \mathrm{~m}$ buffers between each plot to eliminate contamination from adjacent plots.

Average monthly temperature and rainfall for the experimental period were obtained from the Grasslands AgResearch weather station (approximately $1 \mathrm{~km}$ away from the study site).

The soil was a Tokomaru silt loam, and 40 samples $(2.5 \mathrm{~cm}$ diameter cores to a depth of $7.5 \mathrm{~cm})$ were taken from across the trial site on 18 November 2008, air dried, passed through a $2 \mathrm{~mm}$ aperture sieve then mixed together. Characteristics of this soil were then ascertained using methods outlined by Blakemore et al. (1987), or by Hesse (1971) for CEC. Soil pH was measured in water at a soil:water ratio of 1:2.5. Phosphate available for plant absorption (expressed as "Olsen P") was determined colorimetrically after extraction in 0.5 $M$ sodium bicarbonate at a soil:water ratio of 1:20. Cation concentrations (specifically $\mathrm{Na}, \mathrm{Mg}, \mathrm{K}$ and $\mathrm{Ca}$ ) were quantified by leaching samples with $1 \mathrm{M}$ ammonium acetate ( $\mathrm{pH} 7.0)$ and determining concentrations in soil:water slurries of 1:50 using atomic absorption spectroscopy. Cation exchange capacity (CEC) was determined by the summation of the extractable cations and the extractable acidity, with the extractable acidity being determined by the decrease in $\mathrm{pH}$ of the extraction solution. Soil organic matter was estimated by measuring total carbon, which was determined by heating soil in a stream of high purity oxygen in a Leco furnace to produce $\mathrm{CO}_{2}$ and measuring this with an infrared detector.

\section{Field treatments}

The experiment was conducted from December 2008 to December 2009. A randomised block design (blocked depending on proximity of plots to each other within the field) was used that consisted of three replicated blocks of 12 treatments including an untreated control (Table 1). Herbicides were applied either at the recommended rate for managing broom or gorse (metsulfuron, clopyralid, triclopyr, triclopyr/picloram mixture) or at the highest rate of the recommended range (hexazinone, terbuthylazine, terbuthylazine/hexazinone mixture), and some herbicides were also applied at half this rate (metsulfuron, clopyralid, hexazinone, terbuthylazine).

Each herbicide was applied to the soil within the allocated plot using a hand-held sprayer with a solid cone nozzle on 4 December 2008 at a rate equivalent to 1,000 $\mathrm{L} \mathrm{ha}^{-1}$ of herbicide solution. A back-and-forth spray pattern was used until all the measured amount of solution had been applied to ensure uniform application of the herbicide. The two treatments that were herbicide mixtures are available commercially already mixed together so were applied as a mixture.

Not surprisingly, some weeds established in the untreated plots during the experiment. Weeds also emerged in some herbicide-treated plots once the herbicide residues began dissipating. These weeds had the potential to adversely affect subsequent bioassays as the roots could regrow in the bioassay pots described below. Therefore, weeds present in the plots were sprayed twice with herbicides containing active ingredients that are deactivated on contact with soil (Young 2013) reducing any potential influence on the treatment effects being measured. This 
Table 1 Details of the herbicide treatments used in the trial

\begin{tabular}{|c|c|c|}
\hline Active ingredient (rate, $\mathrm{kg}$ ai ha ${ }^{-1}$ ) & Trade name* (rate) & Treatment code \\
\hline metsulfuron-methyl (0.10) & Escort $\left(0.17 \mathrm{~kg} \mathrm{ha}^{-1}\right)$ & metsul-L \\
\hline metsulfuron-methyl (0.20) & Escort $\left(0.33 \mathrm{~kg} \mathrm{ha}^{-1}\right)$ & metsul-H \\
\hline clopyralid (1.5) & Versatill $\left(5 \mathrm{~L} \mathrm{ha}{ }^{-1}\right)$ & clopyr-L \\
\hline clopyralid (3.0) & Versatill $\left(10 \mathrm{~L} \mathrm{ha}^{-1}\right)$ & clopyr-H \\
\hline hexazinone (3.75) & Velpar DF $\left(5 \mathrm{~kg} \mathrm{ha}^{-1}\right)$ & hexa-L \\
\hline hexazinone (7.5) & Velpar DF $\left(10 \mathrm{~kg} \mathrm{ha}^{-1}\right)$ & hexa-H \\
\hline terbuthylazine (5.0) & Gardoprim $500\left(10 \mathrm{~L} \mathrm{ha}^{-1}\right)$ & terbu- $L$ \\
\hline terbuthylazine (10.0) & Gardoprim $500\left(20 \mathrm{~L} \mathrm{ha}^{-1}\right)$ & terbu-H \\
\hline terbuthylazine/hexazinone (8.5/1.5) & Agpro Valzine $500\left(20 \mathrm{~L} \mathrm{ha}^{-1}\right)$ & terbu/hexa \\
\hline triclopyr/picloram (3.0/1.0) & Tordon Brushkiller $\left(10 \mathrm{~L} \mathrm{ha}^{-1}\right)$ & tric/pic \\
\hline triclopyr (6.0) & Grazon $\left(10 \mathrm{~L} \mathrm{ha}^{-1}\right)$ & triclo \\
\hline untreated control & NA & untreated \\
\hline
\end{tabular}

*Manufacturers of the products were DuPont (NZ) Ltd (Escort, Velpar DF), DowAgroSciences (NZ) Ltd (Versatill, Grazon, Tordon Brushkiller), Orion Crop Production Ltd (Gardoprim 500) and Agpro (NZ) Ltd (Agpro Valzine 500).

spraying was carried out on 22 December 2008 using glyphosate (Roundup Transorb; $9.2 \mathrm{~g}$ ai $\mathrm{L}^{-1}$ ) and 22 January 2009 using glufosinate (Buster, Bayer (NZ) Ltd; $2.0 \mathrm{~g}_{\text {ai } \mathrm{L}^{-1}}$ ).

\section{Soil sampling}

Soil samples were taken at regular intervals from the plots. The first soil samples were taken one day after the herbicide treatments were applied and then at 2-week intervals until 361 days after treatment (DAT). Three cores were randomly extracted from each treatment plot at each sampling time using a soil corer $(2.5 \mathrm{~cm}$ in diameter and $5 \mathrm{~cm}$ in depth). The soil samples from each plot were combined, mixed and partitioned into three pots to give three sub-samples of residual herbicide levels for each field plot. Pots were each $5 \mathrm{~cm} \times 5 \mathrm{~cm} \times 5 \mathrm{~cm}$ and were $30 \%$ filled (as a bottom layer) with vermiculite to reduce the soil requirement to fill each pot, to assist with drainage of pots and also help adsorb any herbicide leaching out of the soil which might contaminate neighbouring pots.

\section{Bioassay}

A bioassay was developed to determine the time at which the residual herbicide was no longer at a high enough concentration to prevent the establishment of broom seeds. Broom seeds were obtained on 8 August 2008 by removing soil from beneath mature broom plants growing at the Veterinary Large Animal Teaching Unit of Massey University $\left(40^{\circ} 23^{\prime} \mathrm{S}, 175^{\circ} 37^{\prime} \mathrm{E}\right)$. The seeds extracted from this soil were laid out on filter paper overnight to dry at room temperature then stored in paper bags at $5^{\circ} \mathrm{C}$ until the experiment commenced. To maximise the germination of the seed, mature broom seeds were selected on the basis of hardness. All soft seeds were discarded as they were considered less viable than hard ones. The selected hard seeds were scarified using a Forsberg scarifier (a drum lined with P100-grit sand paper) and rotated for 20 seconds at 1425 revolutions per minute to abrade the seed coat. Scarified seeds were treated with thiram powder (800 $\mathrm{g} \mathrm{ai} \mathrm{kg}^{-1}$ as Thiram $80 \mathrm{~W}$, Yates (NZ) Ltd) to prevent fungal infection, and six seeds were sown 1 $\mathrm{cm}$ deep into each pot of soil within a day of taking the soil samples.

Pots were arranged in a randomised layout on a bench in a glasshouse in which the mean monthly temperatures ranged from $16.1^{\circ} \mathrm{C}$ in October 2009 to $20.3^{\circ} \mathrm{C}$ in January 2010. Pots were watered three times per day by a subsurface irrigation system to ensure that the soil remained moist, with water being added to felt mats under the pots from where it moved into pots by capillary flow.

\section{Data collection and measurements}

The number of live seedlings per pot was recorded fortnightly. Each set of soil samples was kept for $c a .60$ days to allow time for broom seeds to germinate and grow. After this time, all living broom seedlings from each treatment pot were cut at the base of their stems and the above-ground components were oven dried at $80^{\circ} \mathrm{C}$ to a constant mass then weighed.

Once there was no visible difference in seedling health between a herbicide treatment and the corresponding untreated control treatment, the soil sampling for that treatment was terminated. Sampling for most herbicide treatments had been terminated by 253 DAT but sampling of triclopyr/picloram and terbuthylazine/hexazinone treatments continued until 361 DAT. 


\section{Data analysis}

All statistical analyses were conducted using SAS 9.2 (SAS Institute Inc 2008). For each herbicide treatment sample, both survival to 60 days (the number of seedlings that emerged and survived in each pot) and biomass were expressed as a fraction of the untreated control treatment for the appropriate block. The data were checked for homogeneity and normality before analysis. They were found to be normally distributed so no transformations were necessary. The following twoparameter logistic model (Equation 1) was fitted to the repeated measures (batches) of residual herbicide,

$$
y=\exp (a+b t) /(1+\exp (a+b t))
$$

where $y$ is the seedling survival or biomass, expressed as a fraction of the untreated control for each period, $a$ and $b$ are empirical parameters, and $t$ is the time (in days) after treatment that each batch was sampled. This logistic model was selected as it is a flexible functional form with only two parameters and has the useful property that predictions are constrained between zero and one. Biomass data in which treated pots exceeded the biomass of untreated pots were assumed to have a value of one for this analysis. The accuracy of the models was determined by the coefficient of determination $\left(R^{2}\right)$. Plots of residuals against predicted values showed little apparent bias for any of the fitted models.

Through rearranging Equation 1 to output time, $T_{i}$, the estimated time ( $T_{i}$, days) to 50 and $95 \%$ survival (i.e. $T s_{50}$ and $T s_{95}$, respectively) and to 50 and $75 \%$ biomass (i.e. $T b_{50}$ and $T b_{75}$, respectively) of the untreated control were derived from each nonlinear regression equation.
Relative survival and biomass at 113, 211 and 253 DAT were analysed with one-way analysis of variance (ANOVA). The logistic parameters $a, b$ and the obtained $T_{i}$ values were also subjected to ANOVA to test the hypothesis of equality between herbicide treatments using the model shown in Equation 2 that accommodated the underlying randomised block design:

$$
Y_{i j}=\mu+\tau_{i}+B_{j}+\varepsilon_{i j}
$$

where $Y_{i j}$ is the value observed for treatment $i$ and block $j, \mu$ is overall mean, $\tau_{i}$ is a fixed effect associated with the $i$ th treatment $(i=1-11), B_{j}$ is a random effect associated with $j$ th block $(j=1-3)$ and $\varepsilon_{i j}$ is the random variation. Where there were significant differences among the treatment least square means, a Tukey's honestly significant difference (HSD) test was used to undertake multiple comparison testing.

\section{Results}

Soil at the site had a mean $\mathrm{pH}$ of 5.2 and an Olsen-P of $43 \mu \mathrm{g} \mathrm{mL} \mathrm{m}^{-1}$. The $\mathrm{Na}, \mathrm{Mg}, \mathrm{K}$ and Ca levels averaged 0.16,

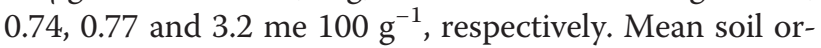
ganic matter was 5.3\% and mean CEC was 13 me $100 \mathrm{~g}^{-1}$. The maximum daily temperature ranged from $22.6^{\circ} \mathrm{C}$ in January to $11.8^{\circ} \mathrm{C}$ in June (Figure 1 ).

Several techniques were assessed prior to the bioassay experiment to determine the most appropriate method for maximising the germination of broom seeds (data not shown). The technique chosen (see Methods section) provided the best germination rate $(86.5 \%$ healthy seedlings, mean of four replicates each with 50 seeds).

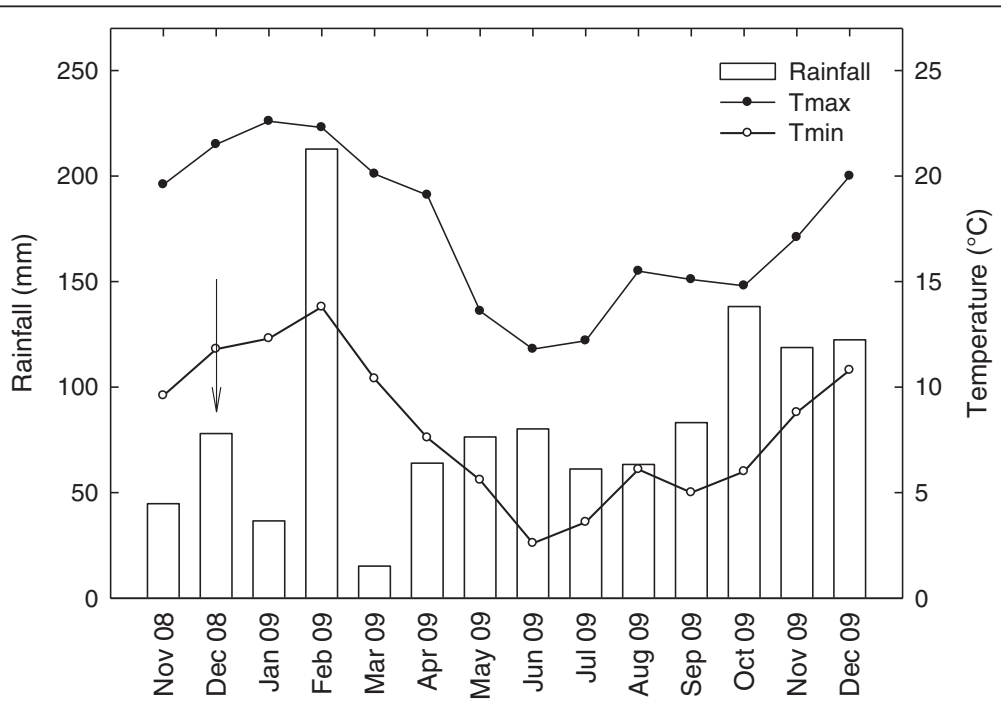

Figure 1 Climate data for the field plots in which residual herbicides were applied. Data are mean total monthly rainfall (mm) and mean monthly maximum $\left(T_{\max }\right)$ and minimum $\left(T_{\min }\right)$ temperature $\left({ }^{\circ} \mathrm{C}\right)$ over the duration of the experiment. The arrow shows the time when herbicide treatments were applied. 
Survival and biomass of broom seedlings for each herbicide treatment increased over time when expressed as a proportion of the untreated control treatment. Although the relationships followed the shapes of sigmoid curves, variability among treatments meant the fit of the curves to the data varied in precision and shape (Figure 2) with $R^{2}$ values ranging from 0.80 to 0.98 (survival) and from 0.61 to 0.95 (biomass).

Residual triclopyr/picloram herbicide mixture in the soil adversely affected the survival of establishing broom seedlings for the longest period, with few surviving in the first 180 DAT (Figure 2). Soil treated with the high rate of hexazinone contained sufficient residue to prevent survival of establishing seedlings for 160 days, compared with 150 days for the hexazinone/terbuthylazine mixture, 105 days for the high rate of clopyralid and 90 days for the high rate of terbuthylazine. Soil treated with the high rate of metsulfuron-methyl and the triclopyr treatment did not contain sufficient residual activity to prevent survival of broom seedlings germinating beyond 70 DAT.

Seedling survival was significantly different among treatments until 211 DAT. Treatments were categorised into three groups based on treatment means at 113 DAT. Group 1 was defined as total prevention of seedling survival, Group 2 was defined as survival $<65 \%$ and Group 3 was defined as survival $>65 \%$ (Table 2 ). The triclopyr/picloram mixture and the high rate of hexazinone were in Group 1. Seedling survival increased from 31 to $53 \%$ and 71 to $86 \%$ for these treatments at 211 and 253 DAT, respectively. Both rates of metsulfuron-methyl and the low rates of terbuthylazine and triclopyr were classed as Group 3 because seedling survival increased rapidly with 86 and $78 \%$ of seedlings surviving under the high rate of metsulfuron-methyl and low rate of terbuthylazine at 113 DAT, respectively. The intermediate group of treatments (Group 2) showed a high variation in seedling survival 113 DAT with 65 and 14\% of seedlings surviving the high rate of terbuthylazine and low rate of hexazinone, respectively. No significant difference in seedling survival was found between treatments within Groups 2 and 3 at either 211 or 253 DAT.

Seedling biomass showed a similar pattern to seedling survival with significant differences again between the least and most effective treatments at 113 DAT (Table 2). The same groupings applied to biomass as to survival. Seedling biomass for the triclopyr/picloram mixture and the high rate of hexazinone (Group 1) was reduced by $86 \%$ and $27-37 \%$ at 211 and 253 DAT, respectively. For the least persistent herbicides (Group 3), seedling biomass was only slightly lower than untreated plants 113 DAT, and only reduced by 14 and $31 \%$ under the low and high rates of metsulfuron-methyl, respectively. As occurred with the seedling survival data, the intermediate group showed a high variation in relative biomass. Relative differences among treatments changed over time as the high rate of clopyralid appeared to dissipate less rapidly than the low rate of hexazinone after 211 days. Again, no significant difference in seedling biomass was found between treatments within Groups 2 and 3 at 211 and 253 DAT (Table 2).

Estimates of relative persistence in Table 2 (i.e. Groups 1-3) relied on measurements from a few specific dates, whereas estimates based on the logistic model used data from all of the harvest dates (Table 3). Although the logistic model parameters $a$ and $b$ did not significantly differ among the treatments $(P>0.05)$ for the relative seedling survival and biomass, the estimated time (days) of residual activity did differ significantly among treatments (Table 3). Estimates of the time to reach 50 and $95 \%$ survival, or 50 and $75 \%$ biomass, showed similar trends of relative herbicide dissipation between treatments (Table 2), but with a few differences. Using all four of these estimates, the combined triclopyr/picloram treatment was the most persistent and the two metsulfuron-methyl treatments, triclopyr and the two terbuthylazine treatments were the least persistent.

\section{Discussion}

The bioassay used here as a measure of herbicide persistence involves seeds that were scarified and treated with fungicide. The reason for selecting hard seeds and artificially scarifying them was to ensure that a consistent level of germination would be obtained from each pot. This probably resulted in higher establishment of seedlings than normally occurs in the field although some seeds in the soil would probably be naturally scarified through such mechanisms as fluctuating temperature and moisture within soil breaking the seed coat (MorenoCasasola et al. 1994). However, the broom seedlings in this study were used as indicators of the long-term effectiveness of various herbicides rather than to simulate typical seedling dynamics.

The persistence of herbicides estimated from germination and biomass of broom seedlings was compared with an untreated control. There were some fluctuations within the actual data so the predicted values from the logistic model are likely to provide a more robust estimate of persistence for specific treatments over time. However, it was possible to compare the relative persistence of the various treatments studied here, and the discussion below is based on the modelled data.

Two of the herbicides assessed in this trial, hexazinone and terbuthylazine, were both prohibited for a time from use in certified forests where forest owners subscribe to the principles set out by the FSC. Hexazinone was considered too mobile (so likely to move to surrounding areas), and terbuthylazine was liable to bioaccumulate in 


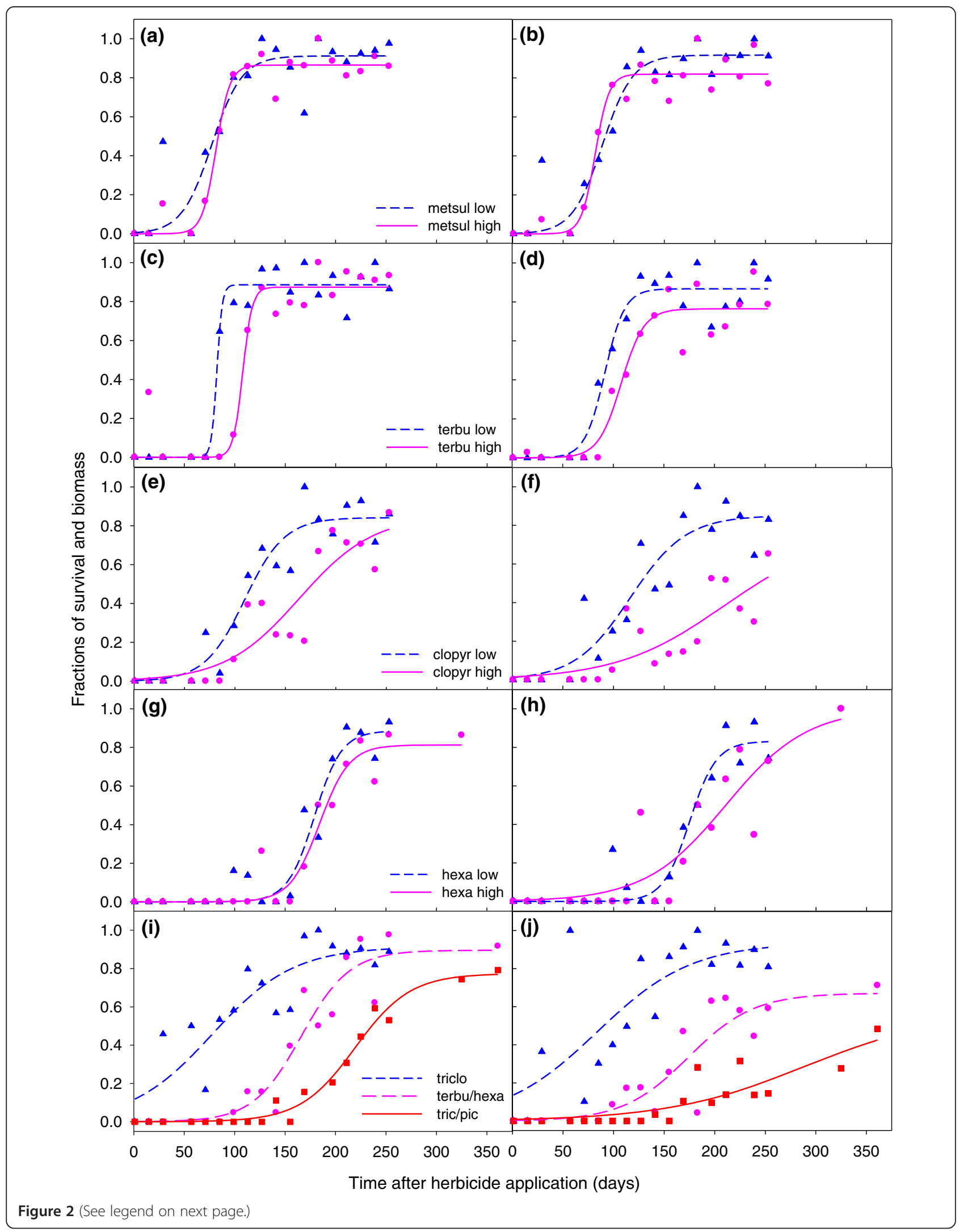


(See figure on previous page.)

Figure 2 Survival (left) and biomass (right) of broom seedlings grown in soil previously treated with herbicides. Treatments were (a, b) metsulfuron, $(\mathbf{c}, \mathbf{d})$ terbuthylazine, $(\mathbf{e}, \mathbf{f})$ clopyralid, $(\mathbf{g}, \mathbf{h})$ hexazinone, $(\mathbf{i}, \mathbf{j})$ triclopyr (triangle), terbuthylazine/hexazinone mixture (filled circle) and triclopyr/picloram mixture (squares). Data are expressed as a proportion of untreated control plants, plotted against the time after herbicide application. The symbols show the measurements (triangles for low rates in a-h, filled circles for high rates in a-h). Curves were fitted to the data using the logistic model described in Equation 1.

soils (Rolando and Watt 2012). A recent decision made by the FSC has resulted in terbuthylazine and hexazinone both being reinstated as acceptable active ingredients for use in certified forests (FSC 2015).

The higher rate of hexazinone used in this trial $(7.5 \mathrm{~kg}$ ai $\mathrm{ha}^{-1}$ ) equates to the maximum rate recommended for pre-plant site preparation (Young 2013) while the lower rate tested here is the highest rate of hexazinone recommended for use in release spraying of radiata pine. Its high cost means that this herbicide is seldom used for site preparation with the more affordable glyphosate/ metsulfuron-methyl mix preferred instead. Both rates (3.75 and $7.5 \mathrm{~kg}$ ai ha ${ }^{-1}$ ) suppressed germination of the majority of broom seedlings for ca. 160 DAT. Differences between these treatments became more evident after this time. The growth of broom seedlings that established 14-20 days after that date were stunted by the remaining herbicide residual activity resulting in less than half the biomass of untreated seedlings for approximately another 20-50 days for low and high rates respectively. The persistence of hexazinone in the soil compared with the other herbicides tested in this experiment provides evidence that this herbicide is useful for managing broom.

Estimates of half-life for hexazinone determined here are broadly consistent with previous published research (Sarmah et al. 2009). The differences in persistence between the two rates of herbicide $\left(7.5 \mathrm{~kg}^{\mathrm{ai} \mathrm{ha}} \mathrm{ha}^{-1}\right.$ and $3.75 \mathrm{~kg}$ ai ha ${ }^{-1}$ ) used in the current trial provide an approximate indication of the half-life of herbicides with one half-life being the time taken for $7.5 \mathrm{~kg}$ to reduce to $3.75 \mathrm{~kg}$ within the soil. The fitted models for these two rates are ca. 20 days apart. Sarmah et al. (2009) determined that the half-life for hexazinone was either 8 or 45 days at $20^{\circ} \mathrm{C}$ for two New Zealand silt loam soils, which is consistent with our result given the temperatures over December and January. They also found the half-life in these two soils increased to 36 or 96 days respectively at $7.5^{\circ} \mathrm{C}$. Their result indicates that the persistence of hexazinone would have been longer in the current study if it had been applied at a cooler time of the year.

Table 2 Effects of residual herbicide activity on survival and biomass of broom seedlings

\begin{tabular}{|c|c|c|c|c|c|c|c|c|c|c|c|c|}
\hline \multirow[t]{2}{*}{ Treatment } & \multicolumn{6}{|c|}{ Survival } & \multicolumn{6}{|c|}{ Relative biomass } \\
\hline & \multicolumn{2}{|c|}{$113 D A T$} & \multicolumn{2}{|c|}{$211 D A T$} & \multicolumn{2}{|c|}{$253 D A T$} & \multicolumn{2}{|c|}{$113 D A T$} & \multicolumn{2}{|c|}{$211 D A T$} & \multicolumn{2}{|c|}{$253 D A T$} \\
\hline \multicolumn{13}{|c|}{ Group 1: most persistent } \\
\hline tric/pic & 0.0 & $d$ & 30.7 & $\mathrm{~b}$ & 53.0 & $\mathrm{a}$ & 0.0 & C & 13.9 & $\mathrm{~b}$ & 14.5 & $\mathrm{~b}$ \\
\hline hexa-H & 0.0 & $d$ & 71.2 & $a b$ & 86.5 & a & 0.0 & C & 63.4 & $a b$ & 72.8 & a \\
\hline \multicolumn{13}{|c|}{ Group 2: intermediate persistence } \\
\hline hexa- $L$ & 13.7 & $\mathrm{~cd}$ & 90.5 & a & 93.2 & a & 7.2 & bc & 91.3 & $\mathrm{a}$ & 74.3 & a \\
\hline terbu/hexa & 15.6 & bcd & 85.7 & $a b$ & 83.3 & $\mathrm{a}$ & 17.2 & bc & 64.4 & $a b$ & 59.1 & a \\
\hline clopyr-H & 39.3 & abcd & 71.2 & $a b$ & 86.7 & $\mathrm{a}$ & 36.8 & $a b c$ & 51.7 & $a b$ & 65.2 & a \\
\hline clopyr-L & 54.3 & abcd & 90.5 & $\mathrm{a}$ & 86.0 & $a$ & 31.1 & $a b c$ & 92.5 & $\mathrm{a}$ & 83.1 & a \\
\hline terbu-H & 65.2 & $a b c$ & 95.2 & a & 93.3 & $a$ & 42.4 & $a b c$ & 67.2 & $a b$ & 78.7 & a \\
\hline \multicolumn{13}{|c|}{ Group 3: least persistent } \\
\hline terbu-L & 77.9 & $a b$ & 71.7 & $a b$ & 86.5 & $\mathrm{a}$ & 71.2 & $a b$ & 77.6 & $\mathrm{a}$ & 91.7 & a \\
\hline triclo & 79.7 & $\mathrm{a}$ & 88.1 & $\mathrm{a}$ & 88.9 & $\mathrm{a}$ & 49.7 & $a b c$ & 93.3 & $\mathrm{a}$ & 80.9 & a \\
\hline metsul-L & 81.0 & a & 88.1 & a & 97.6 & a & 85.7 & a & 90.8 & $\mathrm{a}$ & 91.2 & a \\
\hline metsul-H & 85.7 & $\mathrm{a}$ & 81.0 & $a b$ & 85.9 & a & 68.9 & $a b$ & 89.2 & $\mathrm{a}$ & 76.9 & a \\
\hline \multicolumn{13}{|c|}{ Significance of one-way ANOVA $\left(F_{10,32}\right)$} \\
\hline Treatment & $7.48^{* *}$ & & $2.68^{*}$ & & $1.50^{\mathrm{ns}}$ & & $5.43^{*}$ & & $4.51^{* *}$ & & $6.41^{*}$ & \\
\hline
\end{tabular}

Data are expressed as a percentage of mean untreated control 113, 211 and 253 days after treatment (DAT). Treatments are sorted in an increasing order of survival for 113 DAT. Means within each column followed by the same letter are not significantly different at $a=0.05$. For the analysis of variance (ANOVA), $F$-values are shown, followed by the $P$-category. Values with one, two and three asterisks are significant at $P<0.05,0.01$ and 0.001 , respectively and ${ }^{\text {ns }}$ denotes no significance at $P \geq 0.05$. 
Table 3 Estimated time (days) after herbicide application before broom seedlings reached $\mathbf{5 0}$ and $\mathbf{9 5 \%}$ survival and 50 and $75 \%$ of biomass relative to untreated seedlings

\begin{tabular}{|c|c|c|c|c|c|c|c|c|}
\hline \multirow{3}{*}{$\begin{array}{l}\text { Treatment } \\
\text { tric/pic }\end{array}$} & \multicolumn{4}{|c|}{ Time to reach \% survival (day) } & \multicolumn{4}{|c|}{ Time to reach \% relative biomass (day) } \\
\hline & \multicolumn{2}{|l|}{$T s_{50}$} & \multicolumn{2}{|l|}{$T s_{95}$} & \multicolumn{2}{|l|}{$T b_{50}$} & \multicolumn{2}{|l|}{$T b_{75}$} \\
\hline & 246 & a & 383 & a & 418 & a & 524 & a \\
\hline clopyr-H & 180 & $a b c$ & 310 & $a b$ & 243 & $b$ & 316 & $a b$ \\
\hline hexa-H & 198 & $a b$ & 246 & $a b c$ & 210 & bcd & 245 & $b$ \\
\hline terbu/hexa & 176 & bcd & 245 & $a b c$ & 228 & $b c$ & 299 & $b$ \\
\hline hexa-L & 180 & $a b c$ & 207 & bc & 185 & bcd & 197 & $b$ \\
\hline clopyr-L & 122 & cde & 178 & $b c$ & 131 & bcd & 169 & $b$ \\
\hline terbu-H & 107 & de & 167 & $b c$ & 131 & bcd & 176 & $b$ \\
\hline triclo & 91 & e & 221 & $a b c$ & 100 & $\mathrm{~cd}$ & 133 & $b$ \\
\hline metsul-H & 90 & e & 170 & $b c$ & 94 & $d$ & 132 & $b$ \\
\hline terbu-L & 83 & e & 116 & c & 98 & $\mathrm{~cd}$ & 126 & $b$ \\
\hline metsul-L & 73 & e & 159 & $b c$ & 87 & $d$ & 118 & $b$ \\
\hline \multicolumn{9}{|c|}{ Significance of one-way ANOVA $\left(F_{10,32}\right)$} \\
\hline Treatment & 18.02 & & $5.55^{* * *}$ & & $14.39^{* * *}$ & & $8.92^{* * *}$ & \\
\hline
\end{tabular}

Treatments are sorted in a descending order of herbicide persistence, based both on $T s_{50}$ and $T b_{50}$. Means within each column followed by the same letter are not significantly different at $a=0.05$. For the analysis of variance, $F$-values are shown, and values with three asterisks are significant at $P<0.001$.

Terbuthylazine was one of the less persistent herbicides tested. Residual activity was able to kill most broom seedlings for about 90 days at $10 \mathrm{~kg}$ ai ha ${ }^{-1}$, the highest rate recommended for release spraying in New Zealand pine plantations. Suppression of seedlings to less than half their normal biomass continued until about 130 DAT.

Results from the mixture of hexazinone and terbuthylazine used were intermediate between the two components alone, killing most broom seedlings for about 150 days. Applied in combination at the rate tested here, a terbuthylazine and hexazinone mixture has been the most widely used herbicide for post-plant management of broom (Rolando et al. 2013). This mixture is usually applied during early to late spring so trees can effectively grow weed-free for almost a year. Ideally, grass species would then establish but both terbuthylazine and hexazinone provide management of a broad spectrum of woody and herbaceous weeds, including grasses, so more aggressive weeds than grasses are likely to establish once residual effects dissipate. Thus, broom seeds that do successfully germinate following dissipation of residual herbicide activity are likely to dominate the site as this species generally out-competes other weed species during the establishment of pine plantations.

In contrast, clopyralid, triclopyr and picloram have little effect on grass species and so can be used to promote a shift in vegetation type to either naturally occurring or artificially sown grasses. Watt and Rolando (2014) found that the application of clopyralid on sites dominated by broom promoted a post-control shift in regenerating vegetation to grass species that compete less with trees than broom compared with use of a terbuthylazine/hexazinone mixture. Clopyralid, triclopyr and picloram can also be used in over-sowing operations that predominantly use grass ground covers such as Yorkshire fog (Holcus lanatus L.). Such operations typically occur during early autumn prior to tree planting. Once established, these grasses can reduce germination and establishment of broom seedlings. Moreover, should any broom germinate and establish, clopyralid, triclopyr and picloram can be used to kill the broom during spring with little effect on the grass species. These herbicides can also be used for broom management when establishing trees directly onto pasture sites where there is existing grass cover. Competition from grass immediately around the tree can be removed through spot application of hexazinone/terbuthylazine mixture; otherwise haloxyfop (not tested here) can be used (Rolando et al. 2011). The use of ground covers is an example of a non-chemical weed management strategy encouraged by the FSC (Rolando and Watt 2012).

The most persistent treatment was the triclopyr/picloram mixture. However, this was applied at a rate equivalent to that recommended for killing mature broom plants and other scrub species during pre-plant site preparation (Young 2013). When applied alone, triclopyr was one of the less persistent treatments, indicating that it was the $1.0 \mathrm{~kg}$ ai ha ${ }^{-1}$ of picloram in the triclopyr $/ \mathrm{pi}$ cloram mixture that was responsible for killing most broom seedlings in later weeks. Picloram is well known for being persistent in the soil although its persistence alone was not tested here. MacDiarmid (1975) found residual activity remaining in soil up to 450 DAT when picloram was applied at $1.7 \mathrm{~kg}$ ai $\mathrm{ha}^{-1}$ as an aerial spray 
for the management of gorse. However, this rate of picloram is not safe for selective use over young pine trees. Rates between 10 and $20 \%$ of that used in this trial are recommended for use over young trees to manage establishing broom, and even then, there is a risk of tree distortion (Young 2013). Therefore, the triclopyr/picloram treatment tested is only suitable for site preparation, which is normally almost exclusively undertaken using a mixture of the less expensive glyphosate/metsulfuronmethyl (Gous 2005). On sites to be planted with radiata pine that have a pasture cover with some broom present, the triclopyr/picloram mixture could be quite effective as it would conserve the grass cover and leave residual activity in the soil to discourage any new broom germination. However, the long residual action of this herbicide may prolong the period following application before trees can be safely planted without suffering damage.

In contrast, clopyralid can be applied over young radiata pine trees for selectively managing broom as a release spray treatment at rates as high as $3 \mathrm{~kg}$ ai ha ${ }^{-1}$. Overall, this rate of clopyralid had the second highest duration of residual soil activity, continuing to kill 50\% of seedlings for 175 DAT, with surviving seedlings reaching less than $50 \%$ of the control biomass until 245 DAT, though some seedlings were beginning to establish successfully after 100 days (Figure 2). Clopyralid at half of this rate $\left(1.5 \mathrm{~kg}\right.$ ai ha $\left.{ }^{-1}\right)$ was less effective (Figure 2). Tran et al. (2010) showed that this lower rate of clopyralid (when applied with low rates of triclopyr) could kill 12-month-old broom plants without damaging young radiata pine so further research should investigate whether the higher rate of clopyralid has phytotoxic effects on radiata pine. Harrington (2014) has also identified clopyralid as a useful herbicide for managing emerging broom seedlings for several months after application to soil.

The individual metsulfuron-methyl, triclopyr and terbuthylazine treatments were the least persistent of the herbicides tested as they were not significantly different. Even so, both metsulfuron-methyl rates reduced broom germination and/or growth for about 70 to 90 DAT, which would be useful for killing any broom that germinated soon after spraying. Metsulfuron-methyl is commonly used in combination with glyphosate for site preparation in New Zealand forests, though it is not suitable for release spraying as it is not sufficiently tolerated by radiata pine (Young 2013). Harrington and $\mathrm{He}$ (2010) used similar bioassay techniques to that used here in a number of soil types to determine how many months after metsulfuron-methyl application that lotus (Lotus pedunculatus Cav.), another legume species, could be safely sown within forests as a ground cover. For autumn sowing of lotus, metsulfuron-methyl applied over the previous summer months had safely dissipated if applied more than two months before sowing of the lotus, a similar result to that found with broom in the present work. However, applications during the cooler months of the year meant a delay of more than eight months prior to a spring sowing of lotus to ensure safety. This result illustrated increased persistence under cooler conditions. As with the hexazinone studies cited above, the application of herbicides in December may underestimate the persistence of these herbicides if applied under cooler conditions.

Overall, a combination of clopyralid with appropriate rates of triclopyr and/or picloram has the most potential for managing broom within radiata pine plantings. Such a mixture will not damage grass ground cover so will promote a shift towards naturally occurring grass species. Broom seedlings that do germinate (along with desirable grass seedlings during establishment of ground cover) can be killed within the first year using this herbicide mixture, and residual activity will prevent further broom establishment for about 100 days, by which time grass ground cover should be growing strongly. The broom seedlings that do establish when residual activity declines will be deformed and stunted, and thus will be more susceptible to competition from grass.

\section{Conclusion}

Several of the herbicides routinely used in radiata pine forests can remain active in the soil for a period of time after application to kill or stunt broom seedlings that germinate later. The triclopyr/picloram mixture tested provided the best performance but can only be used at this application rate if applied prior to pine planting. Also, it is not as broad-spectrum or inexpensive as the glyphosate/metsulfuron-methyl mixture normally applied at pre-planting. Both rates of hexazinone also controlled broom seedlings for ca. 160 days after application but will also stop competitive grass swards from forming to discourage broom germination once residual activity dissipates. Clopyralid on its own was less persistent than these other treatments tested but a combination of clopyralid with low rates of triclopyr and/or picloram could provide effective management of broom in New Zealand forests and should be tested using the bioassay system applied here.

\section{Chemical names of herbicides mentioned in text}

Clopyralid (3,6-dichloropyridine-2-carboxylic acid), glufosinate ((2RS)-2-amino-4-[hydroxy(methyl)phosphinoyl] butyric acid), glyphosate ( $N$-(phosphonomethyl)glycine), haloxyfop ((RS)-2-\{4-[3-chloro-5-(trifluoromethyl)-2-pyridyloxy]phenoxy\}propionic acid), hexazinone (3-cyclohexyl-6-dimethylamino-1-methyl-1,3,5-triazine-2,4-dione), metsulfuron-methyl (methyl 2-(4-methoxy-6-methyl1,3,5-trazine-2-ylcarbamoylsulfamoyl)benzoate), picloram 
(4-amino-3,5,6-trichloro-2-pyridinecarboxylic acid), terbuthylazine (N-tert-butyl-6-chloro-N'-ethyl-1,3,5-triazine2,4-diamine), triclopyr ([(3,5,6-Trichloro-2-pyridinyl)oxy] acetic acid).

\section{Competing interests}

The authors declare that they have no competing interests.

\section{Authors' contributions}

HT was the primary author, applied treatments, conducted bioassays and analysed the data. $\mathrm{KCH}$ designed the trial, assisted with treatments and wrote parts of the paper. AWR and MSW helped with data analysis and writing. All authors have read and approved the final manuscript.

\section{Acknowledgements}

We wish to thank the Foundation for Research, Science and Technology (FoRST) and New Zealand's International Aid and Development Agency (NZAID) for financial assistance, the Fertiliser and Lime Research Centre (Massey University) for analysing characteristics of the soil prior to the trial, chemical companies for providing their products, and Mark Osborne and Plant Growth Unit (Massey University) staff for technical assistance. The comments and suggestions of referees and editors on earlier drafts of the paper helped to significantly improve its clarity.

\section{Author details}

'Institute of Agriculture and Environment, Massey University, Palmerston North 4442, New Zealand. ${ }^{2}$ Scion, Fendalton, PO Box 29237, Christchurch 8540, New Zealand.

\section{Received: 12 February 2014 Accepted: 20 April 2015}

\section{Published online: 07 May 2015}

\section{References}

Balandier, P, Collet, C, Miller, JH, Reynolds, PE, \& Zedaker, SM. (2006). Designing forest vegetation management strategies based on the mechanisms and dynamics of crop tree competition by neighbouring vegetation. Forestry, $79(1), 3-27$

Balneaves, JM. (1982). Grass control for radiata pine establishment on drought sites. New Zealand Journal of Forestry, 27(2), 259-276.

Berisford, YC, Bush, PB, \& Taylor, JW, Jr. (2006). Leaching and persistence of herbicides for kudzu (Pueraria montana) control on pine regeneration sites. Weed Science, 54(2), 391-400.

Beyer, EM, Brown, HM, \& Duffy, MJ. (1987). Sulfonylurea herbicide soil relations (Proceedings of the 1987 British Crop Protection Conference - Weeds, 2, pp. 531-540).

Blakemore, LC, Searle, PL, \& Daly, BK. (1987). Methods for chemical analysis of soils (New Zealand Soil Bureau Scientific Report 80).

Bossard, CC. (1990). Secrets of an ecological interloper: ecological studies on Cytisus scoparius (Scotch broom) in California. Davis, USA: University of California.

Bossard, CC, \& Rejmánek, M. (1994). Herbivory, growth, seed production and resprouting of an exotic invasive shrub Cytisus scoparius. Biological Conservation, 67(3), 193-200.

Bovey, RW, \& Richardson, CW. (1991). Dissipation of clopyralid and picloram in soil and seep flow in the blacklands of Texas. Journal of Environmental Quality, 20(3), 528-531.

Caldwell, BA. (2006). Effects of invasive Scotch broom on soil properties in a Pacific coastal prairie soil. Applied Soil Ecology, 32(1), 149-152.

Cameron, JN, \& Stokes, KG. (1978). Efficacy and selectivity of hexazinone in radiata pine (Proceedings of the New Zealand Weed and Pest Control Conference, 31, pp. 58-65).

Clinton, PW, Payn, TW, Sun, OJ, \& Richardson, B. (1995). Impacts of understorey vegetation on radiata pine growth and nutrition. In Second International Conference on Forest Vegetation Management, 20-24 March 1995 (pp. 237-239).

Close, ME, Lee, R, Sarmah, AK, Pang, L, Dann, RL, Magesan, GN, Watt, JPC, \& Vincent, JW. (2008). Pesticide sorption and degradation characteristics in New Zealand soils-a synthesis from seven field trials. New Zealand Journal of Crop and Horticultural Science, 36(1), 9-30.

Coackley, A, \& Moore, RW. (1977). DPX 3674 - A broad spectrum herbicide for weed control in forestry (Proceedings of the New Zealand Weed and Pest Control Conference, 30, pp. 233-237).
Cox, C. (1998). Herbicide factsheet: clopyralid. Journal of Pesticide Reform, $18(4), 15-19$

Cox, C. (2000). Herbicide factsheet: triclopyr. Journal of Pesticide Reform, 20(4), 12-19.

Davenhill, NA. (1997). Forest weed control manual - a guide to herbicide use in forests (FRI Bulletin (Vol. 180)). Rotorua: New Zealand Forest Research Institute Ltd.

Dimock, EJ, Il, Beebe, TF, \& Collard, EB. (1983). Planting-site preparation with herbicides to aid conifer reforestation. Weed Science, 31(2), 215-221.

Feng, JC. (1987). Persistence, mobility and degradation of hexazinone in forest silt loam soils. Journal of Environmental Science and Health, Part B: Pesticides, Food Contaminants, and Agricultural Wastes, 22(2), 221-233.

Fisher, JT, Dudoich, DJ, \& Fancher, GA. (1986). Efficacy of pre- and postemergent herbicides in field-planted Pinus eldarica. Forest Ecology and Management. 16(1-4), 253-258

Fitzgerald, CH, \& Fortson, JC. (1979). Herbaceous weed control with hexazinone in loblolly pine (Pinus taeda) plantations. Weed Science, 27(6), 583-588.

FSC (2015). FSC list of "highly hazardous" pesticides. Bonn, Germany: Forestry Stewardship Council. http://ic.fsc.org/pesticides.88.htm

Gaskin, RE, \& Zabkiewicz, JA. (1986). Comparison of effectiveness and persistence of three hexazinone formulations (Proceedings of the New Zealand Weed and Pest Control Conference, 39, pp. 81-84).

Gous, S. (2005). Herbicides. In M Colley (Ed.), Forestry Handbook (pp. 112-113). Christchurch: New Zealand Institute of Forestry Inc.

Gratkowski, H. (1975). Silvicultural use of herbicides in Pacific Northwest forests (USDA Forest Service General Technical Report, p. PNW-37).

Günther, P, Rahman, A, \& Pestemer, W. (1989). Quantitative bioassays for determining residues and availability to plants of sulphonylurea herbicides. Weed Research, 29(2), 141-146.

Harrington, TB. (2014). Synthetic auxin herbicides control germinating Scotch broom (Cytisus scoparius). Weed Technology, 28(2), 435-442.

Harrington, KC, \& He, XZ. (2010). Determining how soon ground covers can be planted in forests after applying metsulfuron (Proceedings of the 17th Australasian Weeds Conference, pp. 340-343).

Harrington, KC, Rolston, MP, \& Ivens, GW. (1982). Movement of hexazinone spots applied to hill slopes (Proceedings of the New Zealand Weed and Pest Control Conference, 35, pp. 162-165).

Helling, CS. (2005). The science of soil residual herbicides. In RC Acker (Ed.), Soil Residual Herbicides: Science and Management (Vol. 3, pp. 3-22). Sainte-Annede-Bellevue, Canada: Canadian Weed Science Society.

Hesse, PR. (1971). A Textbook of Soil Chemical Analysis. London, UK: John Murray.

Hoshovsky, M. (1986). Element stewardship abstract for Cytisus scoparius and Genista monspessulanus: Scotch broom, French broom. Arlington, VA, USA: The Nature Conservancy.

Ismail, BS, \& Lee, HJ. (1995). Persistence of metsulfuron-methyl in two soils. Journal of Environmental Science and Health, Part B: Pesticides, Food Contaminants, and Agricultural Wastes, 30(4), 485-497.

James, TK, Rahman, A, Holland, PT, McNaughton, DE, \& Heiermann, M. (1998). Degradation and movement of terbuthylazine in soil (Proceedings of the New Zealand Plant Protection Conference, 51, pp. 157-161)

James, TK, Rahman, A, Mellsop, JM, \& Trolove, M. (2004). Effect of rainfall on the movement and persistence of metsulfuron-methyl and clopyralid applied to pasture. New Zealand Plant Protection, 57, 271-276.

Jotcham, JR, Smith, DW, \& Stephenson, GR. (1989). Comparative persistence and mobility of pyridine and phenoxy herbicides in soil. Weed Technology, $3(1), 155-161$

Ketchum, JS, \& Rose, R. (2003). Preventing establishment of exotic shrubs (Cytisus scoparius (L.) Link. and Cytisus striatus (Hill)) with soil active herbicides (hexazinone, sulfometuron, and metsulfuron). New Forests, 25(2), 83-92.

Khan, MA, \& Liang, T. (1989). Mapping pesticide contamination potential. Environmental Management, 13(2), 233-242.

Lavy, TL, Mattice, JD, \& Kochenderfer, JN. (1989). Hexazinone persistence and mobility of a steep forested watershed. Journal of Environmental Quality, 18(4), 507-514

Löf, M. (2000). Establishment and growth in seedlings of Fagus sylvatica and Quercus robur: influence of interference from herbaceous vegetation. Canadian Journal of Forest Research, 30(6), 855-864.

MacDiarmid, BN. (1975). Soil residues of picloram applied aerially to New Zealand brushweeds (Proceedings of the New Zealand Weed and Pest Control Conference, 28, pp. 109-114).

MacDiarmid, BN. (1977). Properties and activity of triclopyr on some New Zealand brushweeds (Proceedings of the New Zealand Weed and Pest Control Conference, 30, pp. 66-70). 
McCracken, IJ. (1995). The effect of understorey broom (Cytisus scoparius) on soil moisture and growth of Pinus radiata (Second International Conference on Forest Vegetation Management, 20-24 March, pp. 208-220).

Michael, JL, \& Neary, DG. (1993). Herbicide dissipation studies in southern forest ecosystems. Environmental Toxicology and Chemistry, 12(3), 405-410.

Morash, R, \& Freedman, B. (1989). The effects of several herbicides on the germination of seeds in the forest floor. Canadian Journal of Forest Research, 19(3), 347-350

Moreno-Casasola, P, Grime, JP, \& Martinez, ML. (1994). A comparative study of the effects of fluctuations in temperature and moisture supply on hard coat dormancy in seeds of coastal tropical legumes in Mexico. Journal of Tropical Ecology, 10(2), 67-86.

Nambiar, E, \& Sands, R. (1993). Competition for water and nutrients in forests. Canadian Journal of Forest Research, 23(10), 1955-1968.

Oneto, SR, Kyser, GB, \& DiTomaso, JM. (2010). Efficacy of mechanical and herbicide control methods for Scotch broom (Cytisus scoparius) and cost analysis of chemical control options. Invasive Plant Science and Management, 3(4), 421-428.

Pik, AJ, Peake, E, Strosher, MT, \& Hodgson, GW. (1977). Fate of 3,6-dichloropicolinic acid in soils. Journal of Agricultural and Food Chemistry, 25(5), 1054-1061.

Prévosto, B, Dambrine, E, Coquillard, P, \& Robert, A. (2006). Broom (Cytisus scoparius) colonization after grazing abandonment in the French Massif Central: impact on vegetation composition and resource availability. Acta Oecologica, 30(2), 258-268

Rahman, A. (1981). Persistence and movement of hexazinone in some New Zealand soils (Proceedings of the 8th Asian Pacific Weed Science Society, 8, pp. 475-479).

Rahman, A, James, TK, Martin, P, \& Fullerton, DK. (1991). Persistence of metsulfuron in different soils (Proceedings of the New Zealand Weed and Pest Control Conference, 44, pp. 99-104).

Rhodes, RC. (1980). Soil studies with ${ }^{14} \mathrm{C}$-labeled hexazinone. Journal of Agricultural and Food Chemistry, 28(2), 311-315.

Richardson, B. (1993). Vegetation management practices in plantation forests of Australia and New Zealand. Canadian Journal of Forest Research, 23(10), 1989-2005.

Richardson, B, \& Whitehead, D. (2002). Root-zone water storage and growth of Pinus radiata in the presence of a broom understorey. New Zealand Journal of Forestry Science, 32(2), 208-220.

Richardson, B, Vanner, A, Ray, J, Davenhill, N, \& Coker, G. (1996). Mechanisms of Pinus radiata growth suppression by some common forest weed species. New Zealand Journal of Forestry Science, 26(3), 421-437.

Richardson, B, Vanner, A, Ray, J, \& Balneaves, J. (1997). Effect of some common weed species on Pinus radiata growth at a dry South Island site (Proceedings of the New Zealand Plant Protection Conference, 50, pp. 373-376).

Richardson, B, Kimberley, MO, Ray, JW, \& Coker, GW. (1999). Indices of interspecific plant competition for Pinus radiata in central North Island of New Zealand. Canadian Journal of Forest Research, 29(7), 898-905.

Rolando, CA, \& Watt, MS. (2012). Perspectives on Forest Stewardship Council certification and vegetation management in New Zealand. New Zealand Journal of Forestry, 56(4), 37-40.

Rolando, CA, Gous, S, \& Watt, MS. (2011). Preliminary screening of herbicide mixes for the control of five major weed species on certified Pinus radiata plantations in New Zealand. New Zealand Journal of Forestry Science, 41, 165-175.

Rolando, CA, Garrett, LG, Baillie, BR, \& Watt, MS. (2013). A survey of herbicide use and a review of environmental fate in New Zealand planted forests. New Zealand Journal of Forestry Science, 43: 17.

Roy, DN, Konar, SK, Charles, DA, Feng, JC, Prasad, R, \& Campbell, RA. (1989). Determination of persistence, movement, and degradation of hexazinone in selected Canadian boreal forest soils. Journal of Agricultural and Food Chemistry, 37(2), 443-447.

Sahid, I, \& Teoh, S. (1994). Persistence of terbuthylazine in soils. Bulletin of Environmental Contamination and Toxicology, 52(2), 226-230.

Sarmah, AK, Kookana, RS, \& Alston, AM. (2000). Leaching and degradation of triasulfuron, metsulfuron-methyl, and chlorsulfuron in alkaline soil profiles under field conditions. Australian Journal of Soil Research, 38(3), 617-631.

Sarmah, AK, Close, ME, \& Mason, NWH. (2009). Dissipation and sorption of six commonly used pesticides in two contrasting soils of New Zealand. Journal of Environmental Science and Health, Part B: Pesticides, Food Contaminants, and Agricultural Wastes, 44(4), 325-336.

SAS Institute Inc. (2008). SAS/STAT 9.2 User's Guide. Cary, NC, USA: SAS Institute Inc.

Stephenson, GR, Solomon, KR, Bowhey, CS, \& Liber, K. (1990). Persistence, leachability, and lateral movement of triclopyr (Garlon) in selected Canadian forestry soils. Journal of Agricultural and Food Chemistry, 38(2), 584-588.
Trabue, SL, Palmquist, DE, Lydick, TM, \& Singles, SK. (2006). Effects of soil storage on the microbial community and degradation of metsulfuron-methyl. Journal of Agricultural and Food Chemistry, 54(1), 142-151.

Tran, H, Harrington, KC, Robertson, AW, \& Watt, MS. (2010). Assessment of herbicides for selectively controlling broom (Cytisus scoparius) growing with Pinus radiata (Proceedings of 17th Australasian Weeds Conference, p. 372).

Turner, JH. (1933). The viability of seeds. Bulletin of Miscellaneous Information (Royal Gardens, Kew), 1933(6), 257-269.

USDA-FS (1984a). Pesticide Background Statements. Vol. 1. Herbicides. Hexazinone. Agriculture Handbook 633: Washington, DC: U.S. Department of Agriculture. Pp. $\mathrm{H} 1-\mathrm{H} 86$.

USDA-FS (1984b). Pesticide background statements. Vol. 1. Herbicides. Triclopyr. Agriculture Handbook 633: Washington, DC: U.S. Department of Agriculture. Pp. T1-T62

Wagner, RG, Little, KM, Richardson, B, \& Mcnabb, K. (2006). The role of vegetation management for enhancing productivity of the world's forests. Forestry, 79(1), 57-79

Walker, A, \& Welch, SJ. (1989). The relative movement and persistence in soil of chlorsulfuron, metsulfuron-methyl and triasulfuron. Weed Research, 29(5), 375-383.

Walker, A, Cotterill, EG, \& Welch, SJ. (1989). Adsorption and degradation of chlorsulfuron and metsulfuron-methyl in soils from different depths. Weed Research, 29(4), 281-287.

Walstad, JD, \& Kuch, PJ. (1987). Forest Vegetation Management for Conifer Production. New York, USA: John Wiley.

Wang, GG, Su, J, \& Wang, JR. (2000). Height growth of planted black spruce seedlings in response to interspecific vegetation competition: a comparison of four competition measures at two measuring positions. Canadian Journal of Forest Research, 30(4), 573-579.

Wang, H, Lin, K, Hou, Z, Richardson, B, \& Gan, J. (2010). Sorption of the herbicide terbuthylazine in two New Zealand forest soils amended with biosolids and biochars. Journal of Soils and Sediments, 10(2), 283-289.

Watt, MS, \& Rolando, CA. (2014). Alternatives to hexazinone and terbuthylazine for the chemical control of Cytisus scoparius in Pinus radiata plantations in New Zealand. Weed Research, 54(3), 265-273.

Watt, MS, Whitehead, D, Richardson, B, Mason, EG, \& Leckie, AL. (2003). Modelling the influence of weed competition on the growth of young Pinus radiata at a dryland site. Forest Ecology and Management, 178(3), 271-286.

Watt, MS, Wang, H, Rolando, CA, Zaayman, M, \& Martin, K. (2010). Adsorption of the herbicide terbuthylazine across a range of New Zealand forestry soils. Canadian Journal Forest Research, 40(7), 1-10.

Wearne, LJ, \& Morgan, JW. (2004). Community-level changes in Australian subalpine vegetation following invasion by the non-native shrub Cytisus scoparius. Journal of Vegetation Science, 15(5), 595-604.

Wearne, LJ, \& Morgan, JW. (2006). Shrub invasion into subalpine vegetation: implications for restoration of the native ecosystem. Plant Ecology, 183(2), 361-376.

White, DE, Witherspoon-Joos, L, \& Newton, M. (1990). Herbaceous weed control in conifer plantations with hexazinone and nitrogen formulations. New Forests, 4(2), 97-105.

Young, S. (2013). New Zealand Novachem Agrichemical Manual. Christchurch, New Zealand: Agrimedia Limited.

\section{Submit your manuscript to a SpringerOpen ${ }^{\odot}$ journal and benefit from:}

- Convenient online submission

- Rigorous peer review

- Immediate publication on acceptance

- Open access: articles freely available online

- High visibility within the field

- Retaining the copyright to your article

Submit your next manuscript at springeropen.com 